\title{
Diethyl citrate and sodium citrate reduce the cytotoxic effects of nanosized hydroxyapatite crystals on mouse vascular smooth muscle cells
}

This article was published in the following Dove Press journal:

International Journal of Nanomedicine

\author{
Chong-Yu Zhang' \\ Xin-Yuan Sun' \\ Jian-Ming Ouyang' \\ Bao-Song Gui
}

'Institute of Biomineralization and Lithiasis Research, Jinan University, Guangzhou, ${ }^{2}$ Department of

Nephrology, The Second Hospital of Xi'an Jiaotong University, Xi'an, People's Republic of China
Correspondence: Jian-Ming Ouyang Department of Chemistry, Jinan University, 60I Huangpu Avenue West, Guangzhou 510632, People's Republic of China Tel +86208522 3353

Email toyjm@jnu.edu.cn
Objective: This study aimed to investigate the damage mechanism of nanosized hydroxyapatite (nano-HAp) on mouse aortic smooth muscle cells (MOVASs) and the injury-inhibiting effects of diethyl citrate $\left(\mathrm{Et}_{2} \mathrm{Cit}\right)$ and sodium citrate $\left(\mathrm{Na}_{3} \mathrm{Cit}\right)$ to develop new drugs that can simultaneously induce anticoagulation and inhibit vascular calcification.

Methods: The change in cell viability was evaluated using a cell proliferation assay kit, and the amount of lactate dehydrogenase (LDH) released was measured using an LDH kit. Intracellular reactive oxygen species (ROS) and mitochondrial damage were detected by DCFH-DA staining and JC-1 staining. Cell apoptosis and necrosis were detected by Annexin V staining. Intracellular calcium concentration and lysosomal integrity were measured using Fluo-4/AM and acridine orange, respectively.

Results: Nano-HAp decreased cell viability and damaged the cell membrane, resulting in the release of a large amount of LDH. Nano-HAp entered the cells and damaged the mitochondria, and then induced cell apoptosis by producing a large amount of ROS. In addition, nano-HAp increased the intracellular $\mathrm{Ca}^{2+}$ concentration, leading to lysosomal rupture and cell necrosis. On addition of the anticoagulant $\mathrm{Et}_{2} \mathrm{Cit}$ or $\mathrm{Na}_{3} \mathrm{Cit}$, cell viability and mitochondrial membrane potential increased, whereas the amount of $\mathrm{LDH}$ released, ROS, and apoptosis rate decreased. $\mathrm{Et}_{2} \mathrm{Cit}$ and $\mathrm{Na}_{3}$ Cit could also chelate with $\mathrm{Ca}^{2+}$ to inhibit the intracellular $\mathrm{Ca}^{2+}$ elevations induced by nano-HAp, prevent lysosomal rupture, and reduce cell necrosis. High concentrations of Et ${ }_{2} \mathrm{Cit}$ and $\mathrm{Na}_{3}$ Cit exhibited strong inhibitory effects. The inhibitory capacity of $\mathrm{Na}_{3} \mathrm{Cit}$ was stronger than that of $\mathrm{Et}_{2} \mathrm{Cit}$ at similar concentrations.

Conclusion: Both $\mathrm{Et}_{2} \mathrm{Cit}$ and $\mathrm{Na}_{3}$ Cit significantly reduced the cytotoxicity of nano-HAp on MOVASs and inhibited the apoptosis and necrosis induced by nano-HAp crystals. The chelating function of citrate resulted in both anticoagulation and binding to $\mathrm{HAp}$. $\mathrm{Et}_{2} \mathrm{Cit}$ and $\mathrm{Na}_{3} \mathrm{Cit}$ may play a role as anticoagulants in reducing injury to the vascular wall caused by nano-HAp.

Keywords: vascular calcification, hydroxyapatite, diethyl citrate, sodium citrate, cardiovascular disease

\section{Introduction}

Cardiovascular disease (CVD) is the leading cause of mortality in patients with end-stage renal disease (ESRD), and vascular calcification (VC) is the major contributor to the CVD burden and mortality of patients with ESRD. ${ }^{1,2}$

$\mathrm{VC}$ is a physiological process that predominantly involves the apoptosis of vascular smooth muscle cells (VSMCs) and the phenotypic transformation of VSMCs into osteoblast-like cells. ${ }^{3,4}$ During calcification, $\mathrm{Ca}^{2+}$ and $\mathrm{PO}_{4}{ }^{3-}$ released by apoptotic bodies accumulate in or adjacent to the membranes of matrix vesicles (MVs). Calcium 
phosphate minerals precipitate when sufficient $\mathrm{Ca}^{2+}$ and $\mathrm{PO}_{4}{ }^{3-}$ have accumulated within MVs. Crystals initially form octacalcium phosphate, which reorganizes and stimulates the epitaxial growth of highly insoluble hydroxyapatite (HAp) ${ }^{5}$ HAp then repeats nucleation and crystallization in the same approach and expands the deposition area. ${ }^{6}$

Liu et $\mathrm{al}^{7}$ found that nanosized calcium phosphate crystals can induce cell calcification by inducing the phenotypic transformation of human aortic VSMCs into osteoblast-like cells, and the degree of cell calcification is positively correlated with the acting time of calcium phosphate crystals. Sage et $\mathrm{al}^{8}$ also found that nanosized hydroxyapatite (nano-HAp) induces the phenotypic transformation of VSMCs into osteoblast-like cells in a concentration-dependent manner. Exogenous calcifying calcium phosphate nanoparticles potentiate the accumulation of smooth muscle-derived apoptotic bodies at the sites of mineralization, which may accelerate VC. ${ }^{9}$ Experiments in vitro and in vivo showed that calcium phosphate ions may act as an initial trigger of atherosclerosis via endothelial damage and further enhance local inflammation through the induction of pro-atherosclerotic cytokines and not by direct tissue calcification or functional changes in anti-calcification proteins. ${ }^{10}$ In addition, calcium phosphate and HAp crystals exert a significant toxic effect on VSMCs that can lead to cell death, ${ }^{11}$ and this toxicity is positively correlated with crystal concentration and acting time. ${ }^{12,13}$ VSMC death can lead to a series of consequences, including inflammation by factors produced from apoptotic and necrotic cells and further promotion to calcification through the generation of nucleation sites on dead cells. These effects may lead to atherosclerotic plaque instability and plaque rupture, which eventually result in myocardial infarction or stroke. ${ }^{14}$

Several calcification inhibitors, such as Fetuin-A and albumin, can inhibit the VC by reducing the death of calcium phosphate-induced VSMCs. ${ }^{11,14}$ However, the damage mechanism of calcium deposition on VSMCs and the inhibition mechanism of calcification inhibitors remain unclear.

Sodium citrate $\left(\mathrm{Na}_{3} \mathrm{Cit}\right)$, a commonly used anticoagulant in hemodialysis that can alleviate excised heart valve calcification, significantly decreases calcium and phosphate levels in valve tissues and reduces irregular and fusiform calcific formations around collagen fibers. ${ }^{15}$ However, heparin, a widely used anticoagulant, does not affect VC in rats with chronic kidney disease (CKD) and secondary hyperparathyroidism. ${ }^{16}$ The three carboxyl groups of citrate can bind strongly to $\mathrm{Ca}^{2+}$ on the HAp surface and prevent further crystal growth and thickening. ${ }^{17}$ Our previous studies showed that the anticoagulant effects of $\mathrm{Na}_{3} \mathrm{Cit}$ and diethyl citrate $\left(\mathrm{Et}_{2} \mathrm{Cit}\right)$ are closely related to chelation of $\mathrm{Ca}^{2+}$ ions to form stable calcium citrate complexes. ${ }^{18-21}$

On the basis of our previous study, we further investigated whether $\mathrm{Na}_{3} \mathrm{Cit}$ or $\mathrm{Et}_{2} \mathrm{Cit}$ can affect the damage on mouse aortic smooth muscle cells (MOVASs) induced by nano-HAp. We also aimed to develop new drugs that can simultaneously act as anticoagulants and inhibit VC to provide new insights into the treatment for patients with $\mathrm{CKD}$ and VC.

\section{Materials and methods Materials and apparatus}

Primary MOVASs were purchased from Shanghai Cell Bank, Chinese Academy of Sciences. Nano-HAp (purity $\geq 97 \%$; particle size less than $100 \mathrm{~nm}$ ) was obtained from Shanghai Aladdin Biochemical Technology Co., Ltd. (Shanghai, People's Republic of China). Cell proliferation assay kit (Cell Counting Kit-8, CCK-8) was purchased from Dojindo Laboratory (Kumamoto, Japan). Et ${ }_{2}$ Cit was synthesized in our laboratory. ${ }^{18}$ It was characterized and identified by elemental analysis, infrared spectroscopy, mass spectrometry, and nuclear magnetic resonance. Its mass fraction was $99.27 \%$ according to the results of thin-layer chromatography and acid value titration tests.

\section{Experimental methods}

\section{Cell culture}

MOVASs were used between passages 4 and 8. Cells were cultured in Dulbecco's Modified Eagle's Medium (DMEM) supplemented with 10\% fetal bovine serum (FBS) (Thermo Fisher Scientific, Waltham, MA, USA), $100 \mathrm{U} / \mathrm{mL}$ penicillin, and $100 \mu \mathrm{g} / \mathrm{mL}$ streptomycin in a $5 \% \mathrm{CO}_{2}$ incubator at $37^{\circ} \mathrm{C}$. Trypsin digestion was adopted for cell propagation. Upon reaching $80 \%-90 \%$ confluence, the cells were rinsed twice with PBS. A certain amount of $0.25 \%$ trypsin digestion solution was then added and maintained for $3-5 \mathrm{~min}$ at $37^{\circ} \mathrm{C}$. The DMEM containing 10\% FBS was added to terminate digestion. The cells were blown gently after trypsin digestion to form a cell suspension for the following experiment.

\section{Characterization of nano-HAp crystals}

The phase composition of the prepared nano-HAp crystals was confirmed by X-ray diffraction (XRD; Rigaku, Tokyo, Japan) with $\mathrm{Cu}-\mathrm{K} \alpha$ radiation and Fourier transform infrared (FT-IR) spectroscopy (Thermo Fisher Scientific). The morphology and size of the nano-HAp crystals were observed using an XL-type environmental scanning electron microscope (Carl Zeiss Meditec AG, Jena, Germany) operated at $30 \mathrm{kV}$. 


\section{CCK-8 to detect cell viability}

Exactly $100 \mu \mathrm{L}$ of MOVAS cell suspension with a cell concentration of $5 \times 10^{4}$ cells $/ \mathrm{mL}$ was seeded per well in 96-well plates and incubated in a $5 \% \mathrm{CO}_{2}$ humidified atmosphere at $37^{\circ} \mathrm{C}$ for $24 \mathrm{~h}$. After incubation with serum-free DMEM for $12 \mathrm{~h}$, the cells were synchronized. The culture medium was removed, and the cells were washed twice with PBS.

The cells were then divided into four groups: (A) control group: only serum-free culture medium was added; (B) nanoHAp injury group: $100 \mu \mathrm{g} / \mathrm{mL}$ nano-HAp crystals (prepared with serum-free medium) was added; (C) $\mathrm{Et}_{2}$ Cit treatment group: 1 and $4 \mathrm{mM} \mathrm{Et}_{2} \mathrm{Cit}$ was added to serum-free medium containing $100 \mu \mathrm{g} / \mathrm{mL}$ nano-HAp crystals; (D) $\mathrm{Na}_{3}$ Cit treatment group: 1 and $4 \mathrm{mM} \mathrm{Na}_{3} \mathrm{Cit}$ was added to serum-free medium containing $100 \mu \mathrm{g} / \mathrm{mL}$ nano-HAp crystals. Each experiment was repeated in six-parallel wells. After incubation for $24 \mathrm{~h}, 10 \mu \mathrm{L}$ of CCK-8 was added to each well, which was incubated for $1.5 \mathrm{~h}$. The absorbance was measured at $450 \mathrm{~nm}$ using a microplate reader (Thermo Multiskan MK3; Thermo Fisher Scientific). Cell viability was determined using the equation below.

$$
\text { Cell viability }(\%)=\frac{\mathrm{A}(\text { Treatment group })}{\mathrm{A}(\text { Control group })} \times 100
$$

\section{Lactate dehydrogenase (LDH) release assay}

Cell density and experimental grouping were similar to those described in the previous section. Each experiment was repeated in six parallel wells as the cell control group was set (inhibitor concentration of 0 ); $100 \mu \mathrm{L}$ of cell culture medium was added to each well.

After incubation for $24 \mathrm{~h}$, the optical density values were measured with a microplate reader according to the $\mathrm{LDH}$ kit test method (Shanghai Beyotime Bio-Tech Co., Ltd., Shanghai, People's Republic of China).

\section{Hematoxylin and eosin (HE) staining}

Exactly $1 \mathrm{~mL}$ of cell suspension with an MOVAS cell concentration of $1.5 \times 10^{5}$ cells $/ \mathrm{mL}$ was seeded per well in 12 -well plates. The experimental grouping was similar to that in the section on CCK-8. After incubation for $24 \mathrm{~h}$, the supernatant was removed, and the cells were washed twice with PBS. The cells were fixed with $4 \%$ paraformaldehyde for $15 \mathrm{~min}$ at room temperature. The cells were then washed three times with PBS. After fixation, the cells were stained with hematoxylin stain (Shanghai Beyotime Bio-Tech Co., Ltd.) and incubated for $15 \mathrm{~min}$. They were then washed three times with distilled water for $2 \mathrm{~min}$ to remove excess stains.
Thereafter, the cells were stained with eosin staining solution for $5 \mathrm{~min}$. The cells were washed three times with distilled water for $2 \mathrm{~min}$ to remove excess eosin. After treatment, the cells were observed under a microscope (CKX41; Olympus, Tokyo, Japan).

\section{Intracellular reactive oxygen species (ROS) assay}

Exactly $2 \mathrm{~mL}$ of cell suspension with an MOVAS cell concentration of $1 \times 10^{5}$ cells $/ \mathrm{mL}$ was seeded per well in six-well plates. The experimental grouping was the same as that in the section on CCK-8. After $24 \mathrm{~h}$ of incubation, the supernatant was aspirated, and the cells were washed twice with PBS and digested with $0.25 \%$ trypsin. Afterward, DMEM supplemented with $10 \%$ FBS was added to terminate digestion. The cells were suspended by pipetting, followed by centrifugation (1,000 rpm, $5 \mathrm{~min})$. The supernatant was aspirated, and the cells were washed once with PBS and centrifuged again to obtain a cell pellet. The cells were stained with $200 \mu \mathrm{L}$ of DCFH-DA (Shanghai Beyotime Bio-Tech Co., Ltd.) and incubated at $37^{\circ} \mathrm{C}$ for 20 min under the dark. The cells were then centrifuged, and the supernatant was removed. The cells were washed once with $500 \mu \mathrm{L}$ of serum-free medium, followed by centrifugation (1,000 rpm, $5 \mathrm{~min}$ ). The supernatant was aspirated, added with $200 \mu \mathrm{L}$ of serum-free medium, and thoroughly mixed. Subsequently, the cells were detected via flow cytometry (FACS Aria; BD Corporation, San Jose, CA, USA).

\section{Measurement of mitochondrial membrane potential} $(\Delta \psi \mathrm{m})$ after cell damage

Cell density and experimental grouping were similar to those in the previous section. After incubation for $24 \mathrm{~h}$, the supernatant was aspirated, and the cells were washed twice with PBS and digested with $0.25 \%$ trypsin. DMEM supplemented with $10 \%$ FBS was added to terminate digestion. The cells were suspended by pipetting, followed by centrifugation (1,000 rpm, $5 \mathrm{~min})$. The supernatant was aspirated, and the cells were washed once with PBS and centrifuged again to obtain a cell pellet. The cells were resuspended by adding and thoroughly mixing $500 \mu \mathrm{L}$ of PBS into a microcentrifuge tube. Finally, the samples were stained with JC-1 stain (Becton Dickinson Bioscience Company, Franklin Lakes, CA, USA) and detected by flow cytometry.

\section{Quantitative analysis of apoptosis rate by Annexin V-FITC/PI double-staining assay}

Cell density and experimental grouping were similar to those in the section on intracellular ROS assay. The supernatant 
was aspirated after incubation for $24 \mathrm{~h}$, and the cells were washed twice with PBS and digested with $0.25 \%$ trypsin. DMEM supplemented with 10\% FBS was then added to terminate digestion. The cells were suspended by pipetting, followed by centrifugation (1,000 rpm, $5 \mathrm{~min})$. The supernatant was aspirated, and the cells were washed once with PBS and centrifuged again to obtain a cell pellet. Exactly $200 \mu \mathrm{L}$ of binding buffer was added and mixed thoroughly. The cells were stained with $5 \mu \mathrm{L}$ of Annexin V-FITC (Becton Dickinson Bioscience Company) and incubated in the dark at room temperature for $10 \mathrm{~min}$. The cells were then centrifuged, and the supernatant was removed. Exactly $200 \mu \mathrm{L}$ of binding buffer was added and mixed thoroughly. Subsequently, $5 \mu \mathrm{L}$ of propidium iodide (PI) was added to stain the cells. After treatment, the cells were detected by flow cytometry.

\section{Detection of intracellular calcium concentration}

Cell density and experimental grouping were similar to those in the section on intracellular ROS assay. After incubation for $24 \mathrm{~h}$, the supernatant was aspirated, and the cells were washed twice with PBS and digested with $0.25 \%$ trypsin. DMEM supplemented with $10 \%$ FBS was then added to terminate digestion. The cells were suspended by pipetting, followed by centrifugation (1,000 rpm, $5 \mathrm{~min}$ ). The supernatant was aspirated, and the cells were washed once with PBS and centrifuged again to obtain a cell pellet. Subsequently, the cells were stained with $200 \mu \mathrm{L}$ of Fluo-4/AM (Shanghai Beyotime Bio-Tech Co., Ltd.) $(5 \mu \mathrm{mol} / \mathrm{L})$ and incubated at $37^{\circ} \mathrm{C}$ for $30 \mathrm{~min}$. Finally, the cells were washed three times with PBS and detected via flow cytometry.

\section{Lysosomal integrity assay}

The cell suspension $(1 \mathrm{~mL})$ with a cell concentration of $1 \times 10^{5}$ cells $/ \mathrm{mL}$ was seeded in 12 -well plates. DMEM containing 10\% FBS was added, and the cells were incubated at $37^{\circ} \mathrm{C}$ for $24 \mathrm{~h}$. The cell medium was removed by suction and washed twice with PBS. The cells were then loaded with $5 \mu \mathrm{g} / \mathrm{mL}$ acridine orange (AO) (Shanghai Beyotime Bio-Tech Co., Ltd.) in DMEM for $15 \mathrm{~min}$. The experimental grouping was the same as that in the section on CCK-8. After incubation for $24 \mathrm{~h}$, the supernatant was aspirated, and the cells were washed three times with PBS. The distribution of AO in each cell was observed under a fluorescence microscope (Leica DMRA2; Leica, Wetzlar, Germany). For fluorescence quantitative assay, $100 \mu \mathrm{L}$ of MOVAS cell suspension with a cell concentration of $5 \times 10^{4}$ cells $/ \mathrm{mL}$ was seeded per well in 96-well plates and stained with AO. After $24 \mathrm{~h}$ of incubation, the cells were washed with PBS prior to fluorescence measurements with excitation at $485 \mathrm{~nm}$ and emission at $530 \mathrm{~nm}$ (green cytoplasmic AO) and $620 \mathrm{~nm}$ (red lysosomal AO). Normal lysosomal integrity $=($ total red fluorescence intensity)/(total green fluorescence intensity). Lysosomal integrity $=[($ total red fluorescence intensity $) /($ total green fluorescence intensity) $\times$ (normal lysosomal integrity)]

\section{Statistical analysis}

Experimental data were expressed as the mean $(\bar{x}) \pm$ standard deviation. The experimental results were analyzed statistically using SPSS 13.0 software (SPSS Inc., Chicago, IL, USA). The differences in the means between the experimental groups and the control group were analyzed using Tukey's test. $p<0.05$ was considered significant.

\section{Results}

\section{Characterization and morphology observation of nano-HAp crystals}

The XRD pattern showed eight characteristic peaks consistent with standard HAp (JCPDS No 09-0432), ${ }^{22}$ indicating that the nanoparticles were phase-pure HAp with low crystallinity (Figure 1A). In the FT-IR spectrum (Figure 1B), the vibration peaks at 3,575 and $3,438 \mathrm{~cm}^{-1}$ were attributed to the $\mathrm{O}-\mathrm{H}$ stretching vibration in HAp, and the vibration peaks at 564 and $610 \mathrm{~cm}^{-1}$ belonged to the asymmetric stretching vibration peaks of $\mathrm{P}-\mathrm{O}$ in the $\mathrm{PO}_{4}{ }^{3-}$ groups; these results were consistent with those of previous studies. ${ }^{23,24}$ SEM revealed that the nanoparticles were homogeneous, needlelike crystals (Figure 1C).

\section{Toxicity of nano-HAp on MOVASs and the inhibitory effects of $\mathrm{Et}_{2} \mathrm{Cit}$ and $\mathrm{Na}_{3} \mathrm{Cit}$} As shown in Figure 2A, nano-HAp exerted a significant toxic effect on MOVASs. After MOVASs were incubated with $100 \mu \mathrm{g} / \mathrm{mL}$ nano-HAp for $24 \mathrm{~h}$, the cell viability decreased from $100 \%$ to $42.6 \%$.

After adding the inhibitor $\mathrm{Et}_{2} \mathrm{Cit}$ or $\mathrm{Na}_{3} \mathrm{Cit}$, cell viability increased from $42.6 \%$ to $52.8 \%-87.6 \%$. In addition, cell viability increased with increasing inhibitor concentration, indicating that both $\mathrm{Et}_{2} \mathrm{Cit}$ and $\mathrm{Na}_{3} \mathrm{Cit}$ could inhibit the damage of nano-HAp on MOVASs. The inhibitory effect of $\mathrm{Na}_{3} \mathrm{Cit}$ was stronger than that of $\mathrm{Et}_{2} \mathrm{Cit}$ at similar concentrations.

\section{Cell membrane damage induced by nano-HAp and the inhibitory effects of $\mathrm{Et}_{2}$ Cit and $\mathrm{Na}_{3} \mathrm{Cit}$}

The destruction of the cell membrane caused by apoptosis and necrosis leads to the release of enzymes from 

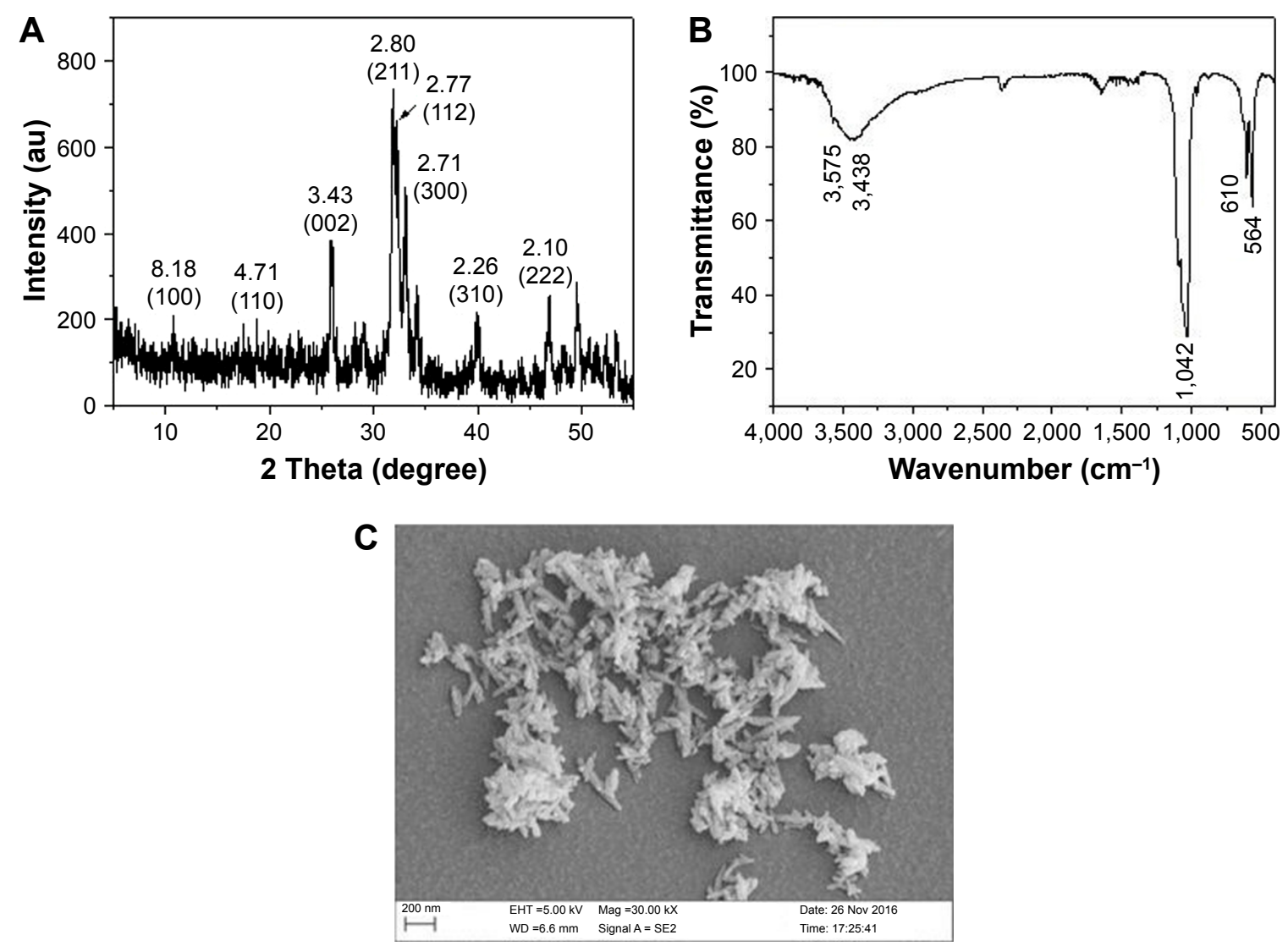

Figure I Characterization of nano-HAp. (A) X-ray diffraction pattern of the nano-HAp. (B) Fourier transform infrared spectrum of nano-HAp. (C) Scanning electron microscopy of particles.

Abbreviation: nano-HAp, nanosized hydroxyapatite.

the cytoplasm to the medium, including LDH whose enzyme activity is relatively stable. That is, the amount of LDH released is an important indicator of cell membrane integrity. ${ }^{25}$ Therefore, after the addition of $\mathrm{Et}_{2} \mathrm{Cit}$ and $\mathrm{Na}_{3} \mathrm{Cit}$, the degree of damage of the cell membrane induced by nanoHAp was quantitatively analyzed by detecting the amount of LDH released.

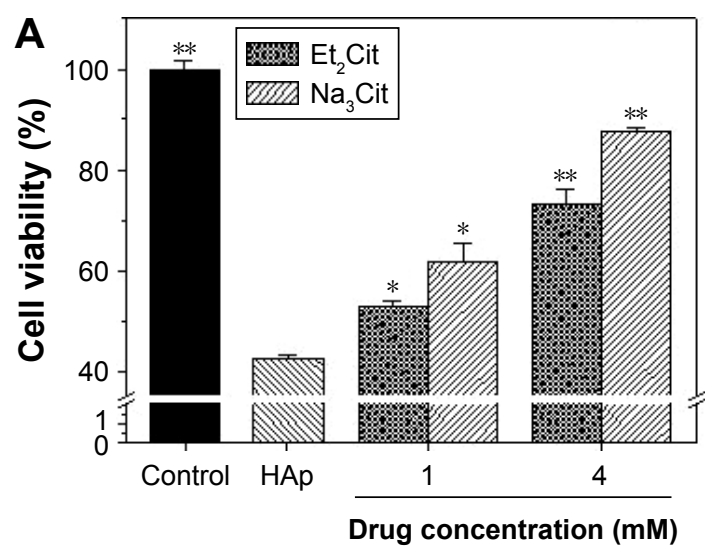

The LDH release amount of MOVASs in the HAp-injured group significantly increased $(22.1 \%)$ compared with that in the normal control group (6.66\%; Figure 2B). After the addition of $\mathrm{Et}_{2} \mathrm{Cit}$ and $\mathrm{Na}_{3} \mathrm{Cit}$, the $\mathrm{LDH}$ release amount decreased from $22.1 \%$ to $8.44 \%-17.78 \%$ in a concentration-dependent manner. This result shows that nano-HAp could damage the cell membrane of MOVASs, and $\mathrm{Et}_{2} \mathrm{Cit}$ and $\mathrm{Na}_{3} \mathrm{Cit}$ could

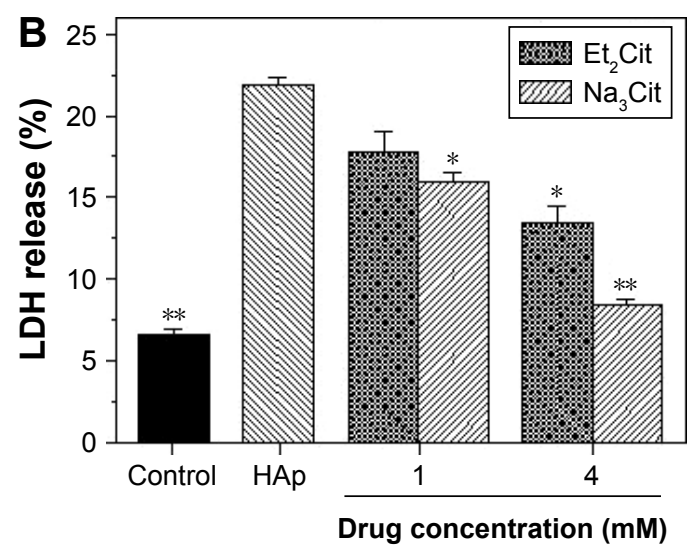

Figure 2 Effects of nano-HAp crystals on $(\mathbf{A})$ cell viability and $(\mathbf{B}) \mathrm{LDH}$ release in the presence of various concentrations of $\mathrm{Et}_{2} \mathrm{Cit}_{\mathrm{t}}$ and $\mathrm{Na}_{3} \mathrm{Cit}$ for $24 \mathrm{~h}\left({ }^{*} \mathrm{p}<0.05\right.$, $* * \mathrm{p}<0.0 \mathrm{I}$ vs nano-HAp).

Abbreviations: $\mathrm{Et}_{2} \mathrm{Cit}$, diethyl citrate; $\mathrm{LDH}$, lactate dehydrogenase; $\mathrm{Na}_{3} \mathrm{Cit}$, sodium citrate; nano-HAp, nanosized hydroxyapatite. 
inhibit such damage. In this work, the inhibitory effect of $\mathrm{Na}_{3} \mathrm{Cit}$ was significantly greater than that of $\mathrm{Et}_{2} \mathrm{Cit}$.

\section{Effect of nano-HAp on cell morphology}

HE staining is the most commonly used method for observing the overall morphology of cells in pathology. Hematoxylin is alkaline, mainly turning chromatin in the nucleus purple and blue. Iraq red is the acid dye, mainly turning the cytoplasm components red or pink.

The cells in the control group were smooth and full, showing a long spindle shape (Figure 3A). By contrast, masses of shrunken cells and chromatin condensation were observed in the HAp-injury group (Figure 3B).

The addition of different concentrations of $\mathrm{Et}_{2} \mathrm{Cit}$ and $\mathrm{Na}_{3}$ Cit significantly increased the number of cells close to the normal cell morphology unlike that in the HAp-injury group. The connection between cells was gradually tightened, and the gap between cells decreased (Figure 3C-F), indicating that both $\mathrm{Et}_{2} \mathrm{Cit}$ and $\mathrm{Na}_{3} \mathrm{Cit}$ could significantly inhibit MOVAS damage induced by nano-HAp. Their inhibitory effects were strong at high concentrations. The inhibitory effect of $\mathrm{Na}_{3} \mathrm{Cit}$ was greater than that of $\mathrm{Et}_{2} \mathrm{Cit}$ at similar concentrations.

\section{Effect of nano-HAp on ROS}

ROS is produced by the reaction between the mitochondria and NADPH oxidase. Excessive ROS can cause inflammation, oxidative stress, and apoptosis. ${ }^{26,27}$ As shown in Figure 4, nano-HAp caused MOVASs to produce a large amount of ROS, indicating that nano-HAp induced cell damage. Both $\mathrm{Na}_{3} \mathrm{Cit}$ and $\mathrm{Et}_{2}$ Cit significantly inhibited ROS production induced by nano-HAp, and strong inhibitory effects were observed at high concentrations (Figure 4B). At the same concentration, the inhibitory capacity of $\mathrm{Na}_{3} \mathrm{Cit}$ was stronger than that of $\mathrm{Et}_{2} \mathrm{Cit}$ in ROS production induced by nano-HAp.

\section{Mitochondrial damage induced by nano- $\mathrm{HAp}$ and inhibitory effects of $\mathrm{Et}_{2} \mathrm{Cit}$ and $\mathrm{Na}_{3} \mathrm{Cit}$}

In normal circumstances, the potential of the inner and outer mitochondrial membranes is in a stable state, maintaining the normal mitochondrial membrane potential $(\Delta \psi \mathrm{m}) .{ }^{28} \mathrm{How}-$ ever, after nanoparticle stimulation in this work, the permeability of the mitochondrial membrane changed and $\Delta \psi \mathrm{m}$ decreased. $\mathrm{Ca}^{2+}$ in mitochondria flew out and caused the dysfunction of the mitochondria. ${ }^{29} \mathrm{JC}-1$ probe is a mitochondrial membrane potential-dependent fluorescent molecule. JC-1 differentially labels mitochondria with high and low $\Delta \psi \mathrm{m}$ by forming J-aggregates or monomers that emit orange-red or green light, respectively. The effect of nano-HAp on $\Delta \psi \mathrm{m}$ detected by JC-1 is shown in Figure 5.

In the control group, the cell ratio of the low potential was $4.07 \%$ (Figure $5 \mathrm{~A}$ ), whereas $\Delta \psi \mathrm{m}$ decreased by $37.21 \%$ in

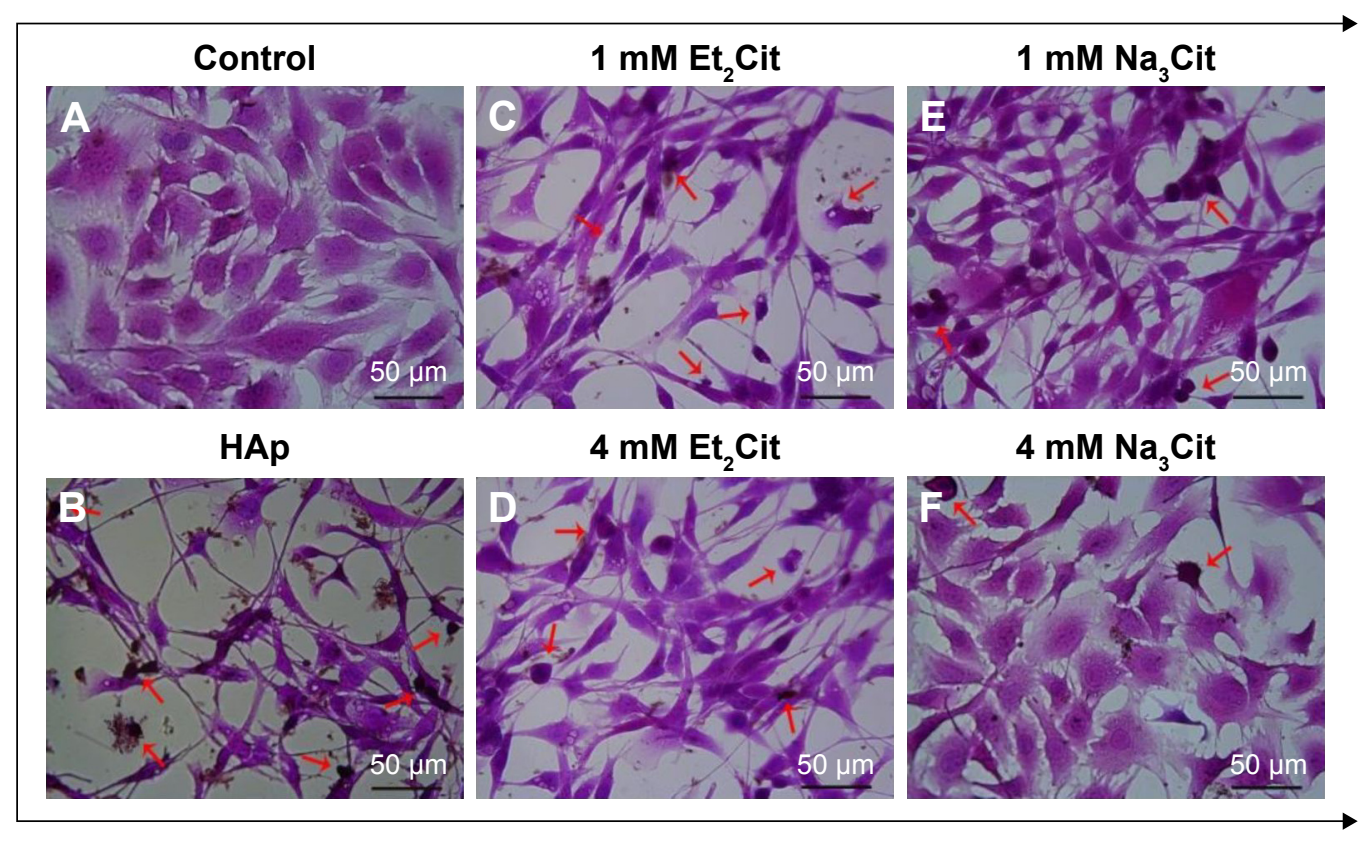

Figure 3 (A) Normal cells; (B) cells treated with $100 \mu \mathrm{g} / \mathrm{mL}$ nano-HAp crystals; (C) cells treated with $100 \mu \mathrm{g} / \mathrm{mL}$ nano-HAp crystals and I mM Et ${ }_{2}$ Cit; (D) cells treated with $100 \mu \mathrm{g} / \mathrm{mL}$ nano-HAp crystals and $4 \mathrm{mM} \mathrm{Et}{ }_{2} \mathrm{Cit}$; (E) cells treated with $100 \mu \mathrm{g} / \mathrm{mL}$ nano-HAp crystals and I mM Na ${ }_{3}$ Cit; (F) cells treated with I00 $\mu \mathrm{g} / \mathrm{mL}$ nano-HAp crystals and $4 \mathrm{mM} \mathrm{Na}_{3} \mathrm{Cit}$. Arrows show the damaged cells, $\times 400$ magnification.

Abbreviations: $\mathrm{Et}_{2} \mathrm{Cit}$, diethyl citrate; MOVASs, mouse aortic smooth muscle cells; $\mathrm{Na}_{3} \mathrm{Cit}$, sodium citrate; nano-HAp, nanosized hydroxyapatite. 

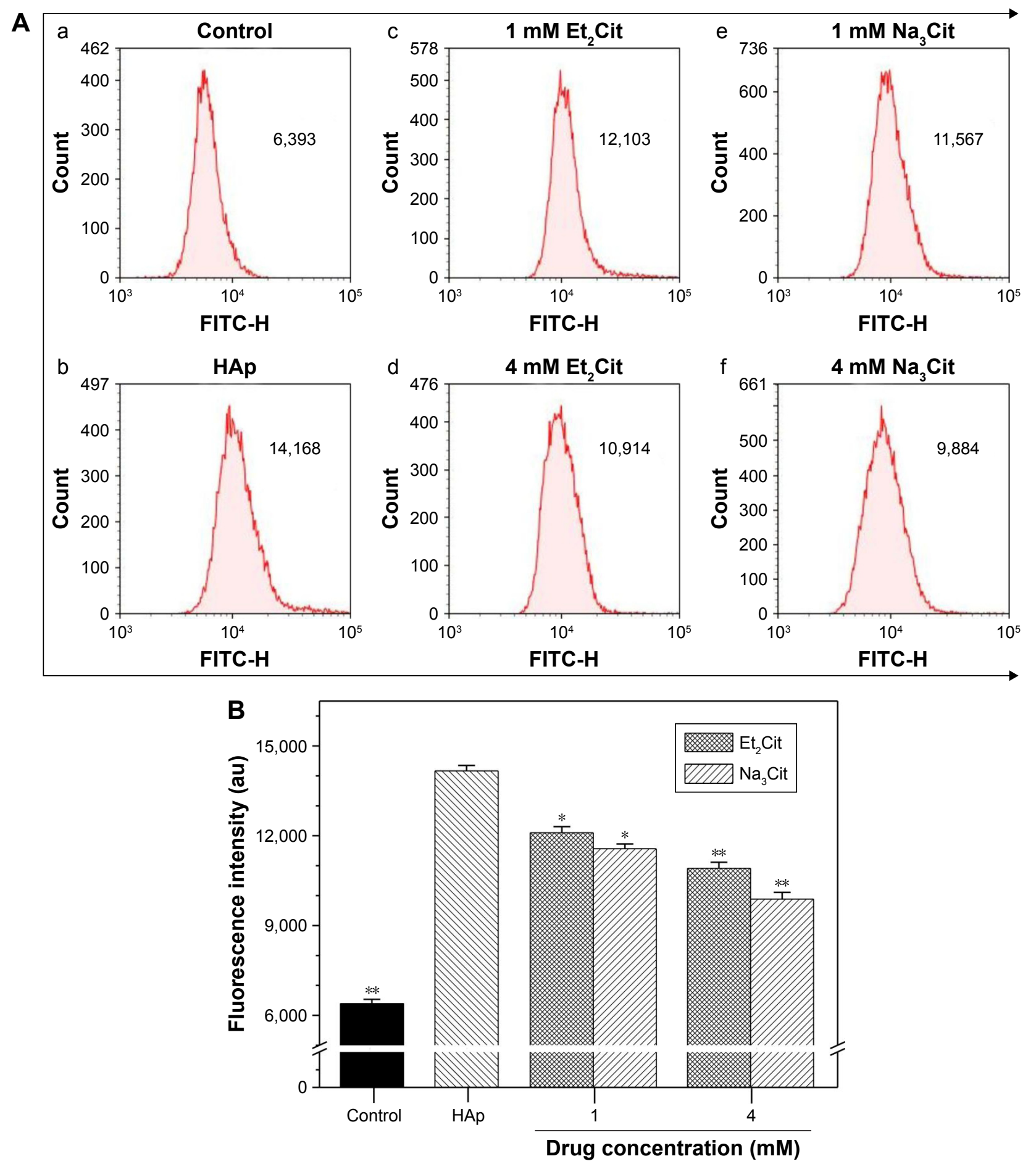

Figure 4 Detection of intracellular ROS level of MOVASs after exposure to $100 \mu \mathrm{g} / \mathrm{mL}$ nano-HAp crystals for $24 \mathrm{~h}$. (A) Histogram of intracellular ROS level. (B) Quantitative fluorescence intensity of intracellular ROS level ( ${ }^{*} p<0.05, * * p<0.01$ vs nano-HAp).

Abbreviations: $\mathrm{Et}_{2} \mathrm{Cit}$, diethyl citrate; MOVASs, mouse aortic smooth muscle cells; $\mathrm{Na}_{3} \mathrm{Cit}$, sodium citrate; nano-HAp, nanosized hydroxyapatite; ROS, reactive oxygen species; FITC-H, fluorescein isothiocyanate-H.

the HAp-injury group (Figure 5B). Thus, nano-HAp could enter the cell to damage the mitochondria.

After the addition of $\mathrm{Na}_{3} \mathrm{Cit}$ or $\mathrm{Et}_{2} \mathrm{Cit}, \Delta \psi \mathrm{m}$ decreased from $37.21 \%$ to $13.35 \%-30.24 \%$, thereby indicating that $\mathrm{Na}_{3} \mathrm{Cit}$ and
$\mathrm{Et}_{2}$ Cit could effectively inhibit mitochondrial damage induced by nano-HAp crystals. Moreover, their inhibitory effects were strong at high concentrations. At the same concentration, the inhibitory effect of $\mathrm{Na}_{3} \mathrm{Cit}$ was stronger than that of $\mathrm{Et}_{2} \mathrm{Cit}$. 


\section{A}

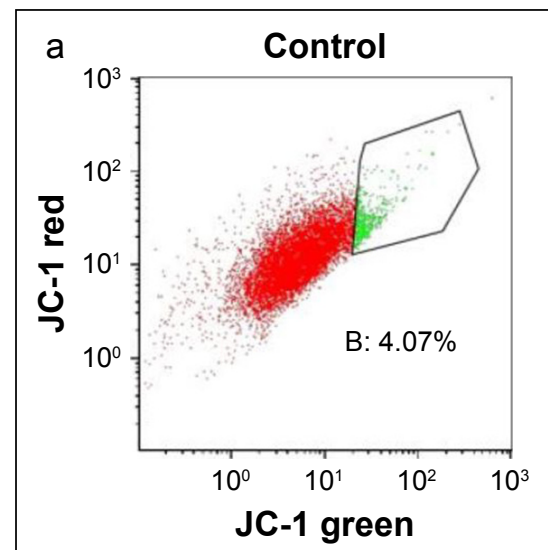

b

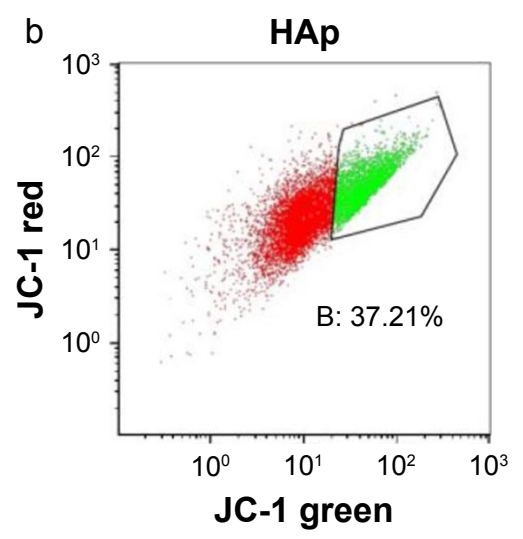

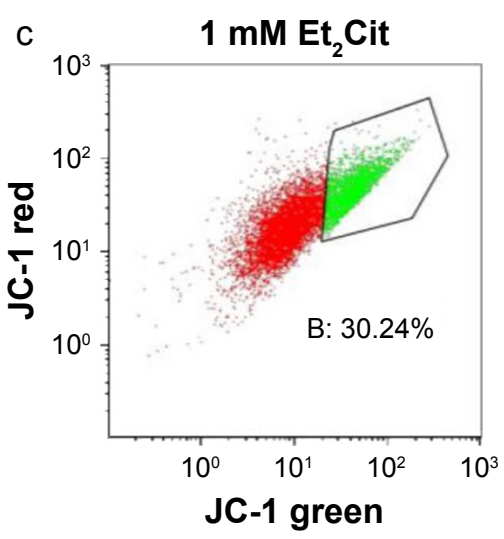

d

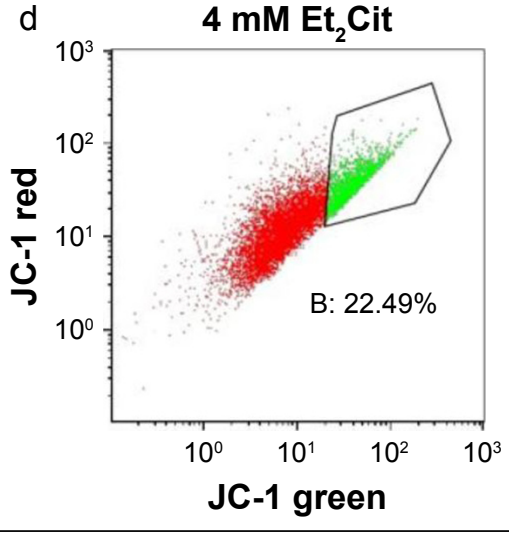

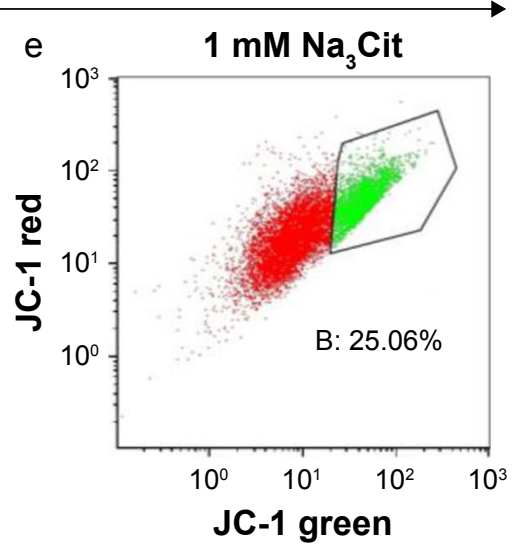

$f$

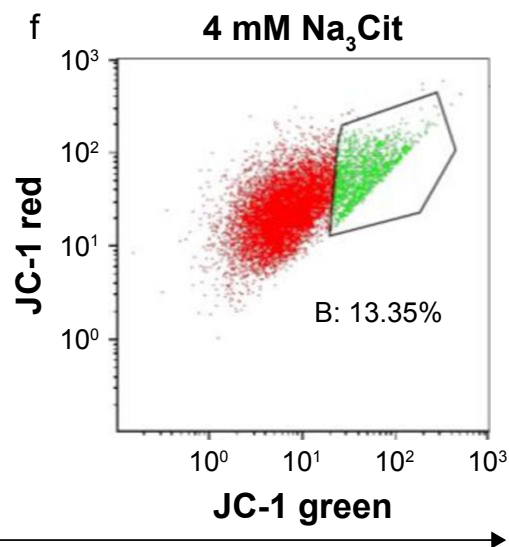

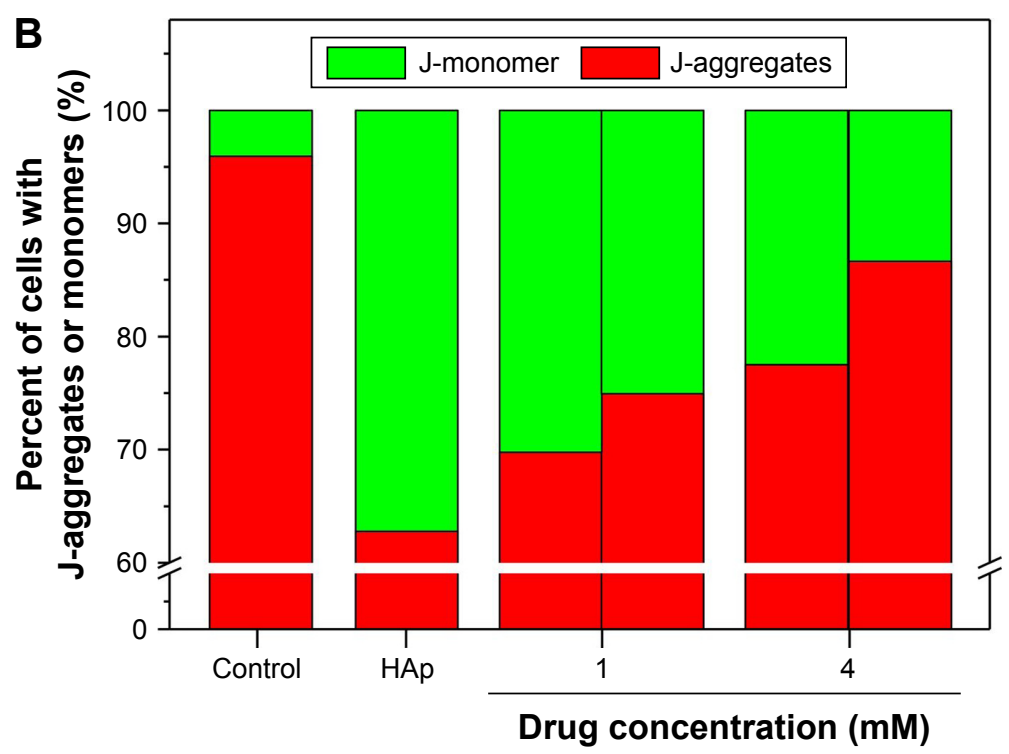

Figure 5 Effects of nano-HAp crystals on mitochondrial membrane potential $(\Delta \psi \mathrm{m})$ of MOVASs in the presence of different concentrations of Et ${ }_{2} \mathrm{Cit}$ and $\mathrm{Na}_{3} \mathrm{Cit}_{\text {for }} 24 \mathrm{~h}$. (A) Dot plots of $\Delta \psi \mathrm{m}$ after incubation with nano-HAp. (B) Quantitative histogram of cells with J-aggregates (red) or monomers (green).

Abbreviations: $\mathrm{Et}_{2} \mathrm{Cit}$, diethyl citrate; MOVASs, mouse aortic smooth muscle cells; $\mathrm{Na}_{3} \mathrm{Cit}$, sodium citrate; nano-HAp, nanosized hydroxyapatite.

\section{HAp-induced cell apoptosis or necrosis and inhibitory effects of $\mathrm{Et}_{2} \mathrm{Cit}$ and $\mathrm{Na}_{3} \mathrm{Cit}$}

In normal cells, phosphatidylserine (PS) is only distributed within the cell membrane lipid bilayer. Cells undergoing early apoptosis are characterized by the translocation of PS to the extracellular membrane; such a process can be detected using Annexin-V. PI is a nucleic acid dye that cannot pass through an intact cell membrane but can permeate late apoptotic cells and dead cell membranes with increasing permeability, leading to 
nuclear red staining. Therefore, Annexin V-FITC/PI double staining can be used to quantitatively detect cell apoptosis. ${ }^{29}$

As shown in Figure 6, the cell early apoptotic rate (Q4) in the control group was $0.47 \%$, whereas that in the HApinjury group reached $9.12 \%$. Nano-HAp clearly induced
MOVAS apoptosis. After the addition of $\mathrm{Na}_{3} \mathrm{Cit}$ or $\mathrm{Et}_{2} \mathrm{Cit}$, the cell apoptosis rate decreased to $2.36 \%-7.57 \%$ (Figure 6A), indicating that $\mathrm{Et}_{2} \mathrm{Cit}$ and $\mathrm{Na}_{3} \mathrm{Cit}$ effectively inhibited the apoptosis induced by nano-HAp, and the inhibitory effects of $\mathrm{Na}_{3} \mathrm{Cit}$ were stronger than those of $\mathrm{Et}_{2} \mathrm{Cit}$.
A

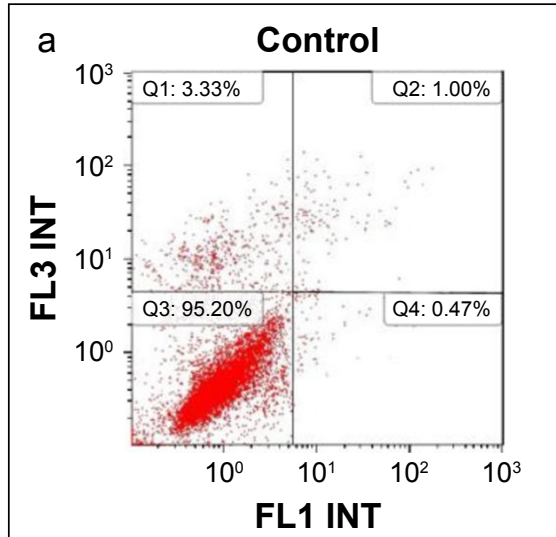

$\mathrm{b}$

b

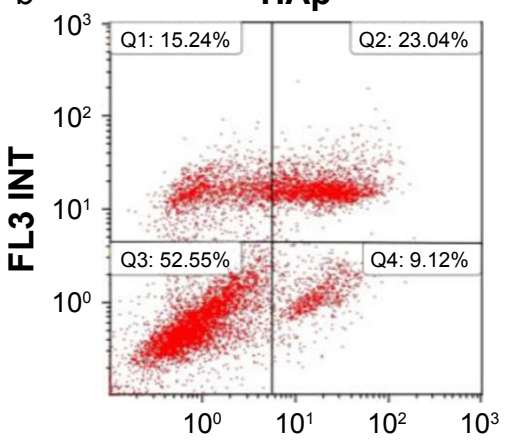

FL1 INT

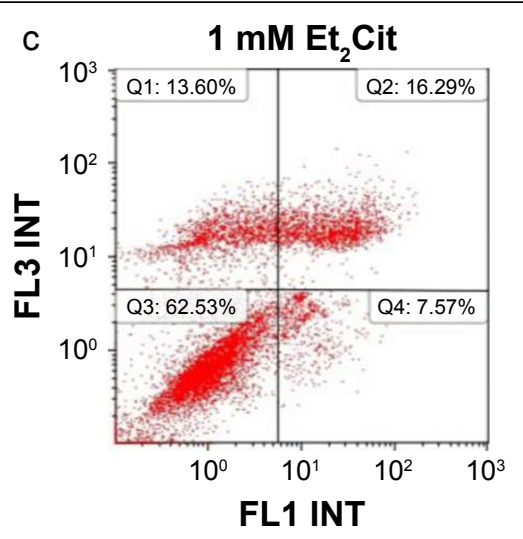

d

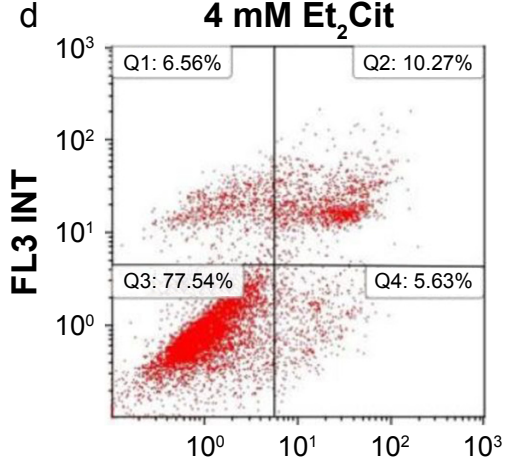

FL1 INT
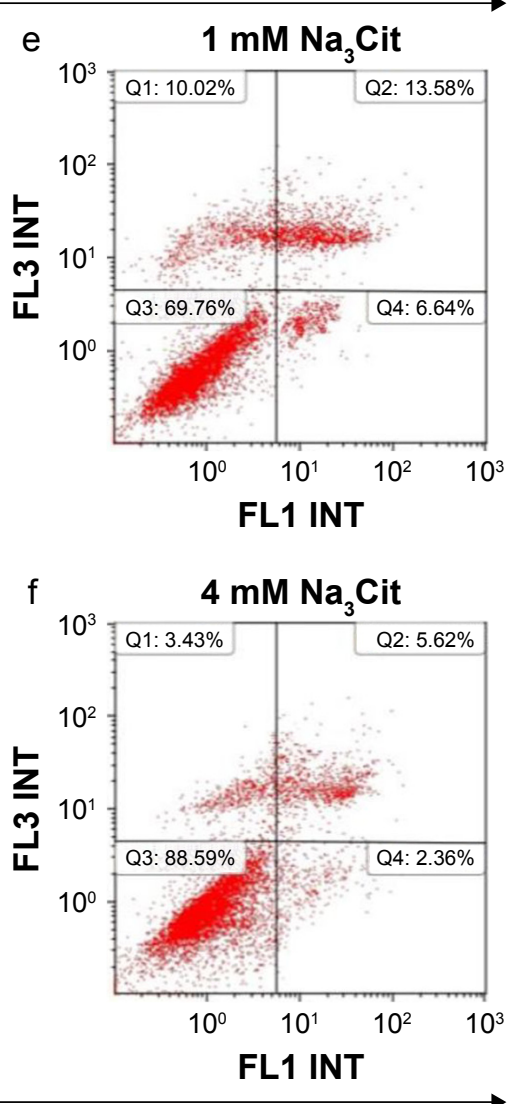

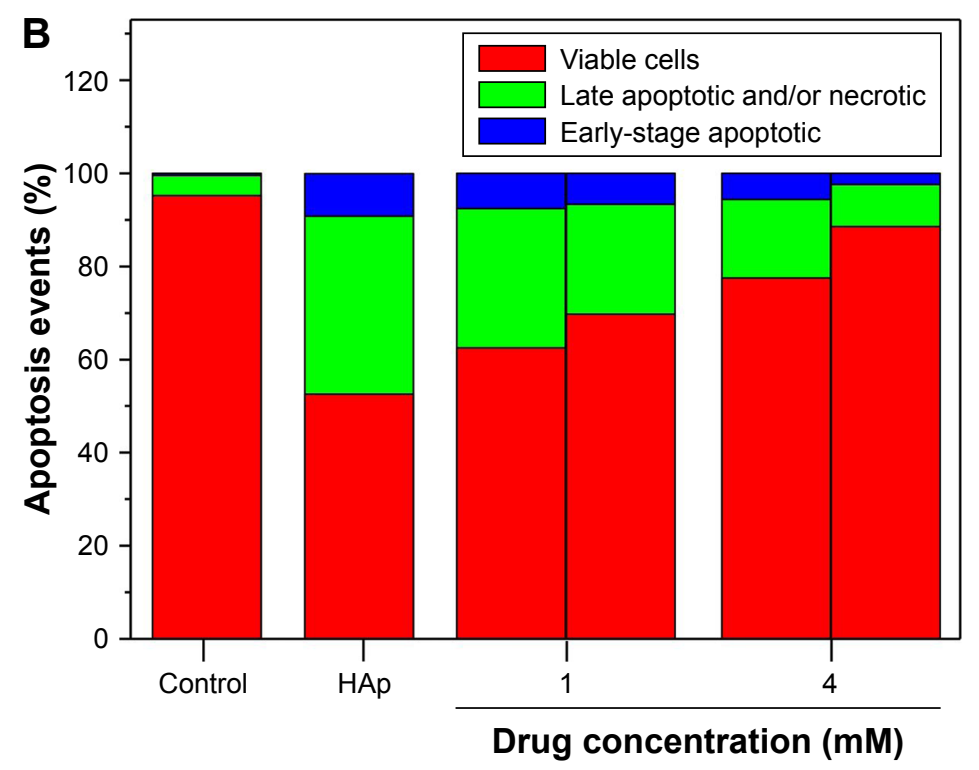

Figure 6 Flow cytometric data of cell death after MOVASs were exposed to nano-HAp crystals in the presence of different concentrations of Et $\mathrm{Cit}_{2}$ and $\mathrm{Na}_{3} \mathrm{Cit}_{\mathrm{t}}$ for $24 \mathrm{~h}$. (A) The representative images of apoptosis and necrosis of MOVASs. (B) Quantitative histogram of cellular apoptosis and necrosis. Quadrants Q1, Q2, Q3, and Q4 denote the ratio of necrotic cells, late apoptotic cells and/or necrotic cells, viable cells, and early-stage apoptotic cells, respectively.

Abbreviations: $\mathrm{Et}_{2} \mathrm{Cit}$, diethyl citrate; MOVASs, mouse aortic smooth muscle cells; $\mathrm{Na}_{3} \mathrm{Cit}$, sodium citrate; nano-HAp, nanosized hydroxyapatite. 
In addition, nano-HAp resulted in the late apoptosis and/or necrosis of a large number of cells (Q1 + Q2, 38.28\%). However, the late apoptotic and/or necrosis rates decreased to $9.05 \%-29.89 \%$ after the addition of $\mathrm{Et}_{2} \mathrm{Cit}$ or $\mathrm{Na}_{3} \mathrm{Cit}$ simultaneously. The above result revealed that both $\mathrm{Et}_{2} \mathrm{Cit}$ and $\mathrm{Na}_{3} \mathrm{Cit}$ effectively inhibited the cell necrosis induced by nano-HAp, and the inhibitory effects of $\mathrm{Na}_{3} \mathrm{Cit}$ were stronger than those of $\mathrm{Et}_{2} \mathrm{Cit}$.

\section{Reduction in nano-HAp-induced intracellular calcium concentration by $\mathrm{Et}_{2} \mathrm{Cit}$ and $\mathrm{Na}_{3} \mathrm{Cit}$}

Excessive intracellular $\mathrm{Ca}^{2+}$ ions can cause cell apoptosis, necrosis, and autophagic death. ${ }^{14,30}$ Fluo-4/AM can bind with intracellular free $\mathrm{Ca}^{2+}$ to produce strong green fluorescence instead of binding with extracellular $\mathrm{Ca}^{2+}$. Thus, the intracellular $\mathrm{Ca}^{2+}$ concentration can be calculated by detecting the percentage of cells stained by Fura-4/AM. ${ }^{31}$

As shown in Figure 7, the percentage of cells stained by Fura-4/AM in the normal control group was $5.07 \%$ (Figure 7A), and it increased to $27.97 \%$ in the HAp-injury group (Figure 7B). This result indicated that nano-HAp caused an obvious increase in the intracellular $\mathrm{Ca}^{2+}$ concentration. After the addition of the inhibitors $\mathrm{Et}_{2} \mathrm{Cit}$ and $\mathrm{Na}_{3} \mathrm{Cit}$ in the HAp-injury group, the percentage of cells stained by Fura-4/AM decreased from $27.97 \%$ in a concentrationdependent manner to $9.16 \%-20.39 \%$ (Figure $7 \mathrm{~B}$ ). At the same concentration, the inhibitory effect of $\mathrm{Na}_{3} \mathrm{Cit}$ was stronger than that of $\mathrm{Et}_{2} \mathrm{Cit}$.

\section{Injury of lysosome induced by nano- $\mathrm{HAp}$ and inhibitory effects of $\mathrm{Et}_{2} \mathrm{Cit}$ and $\mathrm{Na}_{3} \mathrm{Cit}$}

AO can enter the lysosome through the cell membrane and combine with its internal acidic hydrolase to produce orange-red fluorescence. In normal cells or early apoptotic cells, the lysosomal structure remains intact, whereas the intact structure of necrotic cells is destroyed, and orangered fluorescence is minimal. Therefore, the damage degree of cells can be determined by measuring the fluorescence intensity ratio of red and green fluorescence. ${ }^{32}$

As shown in Figure 8, the lysosomal structure of the normal group remained substantially complete, and the red fluorescence superimposed with the green fluorescence and showed strong yellow-orange fluorescence. ${ }^{29}$ However, the red fluorescence was significantly reduced in the HAp-injury group, indicating that nano-HAp damaged the lysosome.

After the addition of $\mathrm{Et}_{2} \mathrm{Cit}$ or $\mathrm{Na}_{3} \mathrm{Cit}$, the red fluorescence intensity in each group was enhanced to different degrees
(Figure 8B). This result indicated that both $\mathrm{Et}_{2} \mathrm{Cit}$ and $\mathrm{Na}_{3} \mathrm{Cit}$ inhibited the lysosomal damage induced by nano-HAp, and the inhibitory effects were strong at high concentrations. At the same concentration, the inhibitory effect of $\mathrm{Na}_{3} \mathrm{Cit}$ was stronger than that of $\mathrm{Et}_{2} \mathrm{Cit}$.

\section{Discussion}

This study was the first to investigate whether $\mathrm{Et}_{2} \mathrm{Cit}$ and $\mathrm{Na}_{3} \mathrm{Cit}$ as anticoagulants can affect the toxicity of nanoHAp crystals on MOVASs. Our data suggested that the mechanism of nano-HAp crystal-induced cell death and cytoprotective effects of $\mathrm{Et}_{2} \mathrm{Cit}$ and $\mathrm{Na}_{3} \mathrm{Cit}$ may involve more than one pathway. The damage mechanism of nano-HAp on MOVASs and the inhibitory effects of $\mathrm{Et}_{2} \mathrm{Cit}$ and $\mathrm{Na}_{3} \mathrm{Cit}$ are shown in Figure 9.

\section{Nano-HAp induces apoptosis of MOVASs and cytoprotective mechanism of $\mathrm{Et}_{2} \mathrm{Cit}$ and $\mathrm{Na}_{3} \mathrm{Cit}$}

The addition of nano-HAp to MOVASs resulted in cell membrane damage and increased membrane permeability; ${ }^{33}$ thus, the cell viability decreased (Figure 2A), and the LDH release amount significantly increased (Figure 2B). However, after the simultaneous addition of $\mathrm{Na}_{3} \mathrm{Cit}$ and $\mathrm{Et}_{2} \mathrm{Cit}$, the cell viability significantly increased, and the $\mathrm{LDH}$ release amount decreased. This result suggested that $\mathrm{Na}_{3} \mathrm{Cit}$ and $\mathrm{Et}_{2} \mathrm{Cit}$ inhibited cell membrane damage. After the damage by nano-HAp, the cell volume decreased, and chromatin became condensed (Figure 3 ). At the same time, $\mathrm{Na}_{3} \mathrm{Cit}$ and $\mathrm{Et}_{2} \mathrm{Cit}$ effectively reduced cell damage. Dautova et $\mathrm{al}^{14}$ found that nano-calcium phosphate crystals cause cell membrane damage, which can be effectively reduced after the addition of calcification inhibitors, such as Fetuin-A and albumin.

The cell membrane damage by nano-HAp leads to the disorder of intracellular electrolytes (such as $\mathrm{Ca}^{2+}$ ions), promotes ROS production through the activation of NADPH oxidase, and induces the intracellular oxidative stress response. ${ }^{34}$ However, $\mathrm{Na}_{3} \mathrm{Cit}$ and $\mathrm{Et}_{2} \mathrm{Cit}$ can inhibit the production of ROS (Figure 4) and reduce the damage of organelles.

Jin et $\mathrm{al}^{35}$ demonstrated that nano-HAp can be internalized into cells, causing mitochondrial membrane permeability and mitochondrial dysfunction. We also observed that nano-HAp can damage the mitochondria and decrease $\Delta \psi m$ (Figure 5). A series of cell responses would finally lead to cell apoptosis (Figure 6). However, both $\mathrm{Na}_{3} \mathrm{Cit}$ and $\mathrm{Et}_{2} \mathrm{Cit}$ could inhibit mitochondrial damage and reduce cell apoptotic death.

Therefore, we hypothesized that nano-HAp may enter the cell through a damaged cell membrane and consequently damage the mitochondria, which induces the production of 

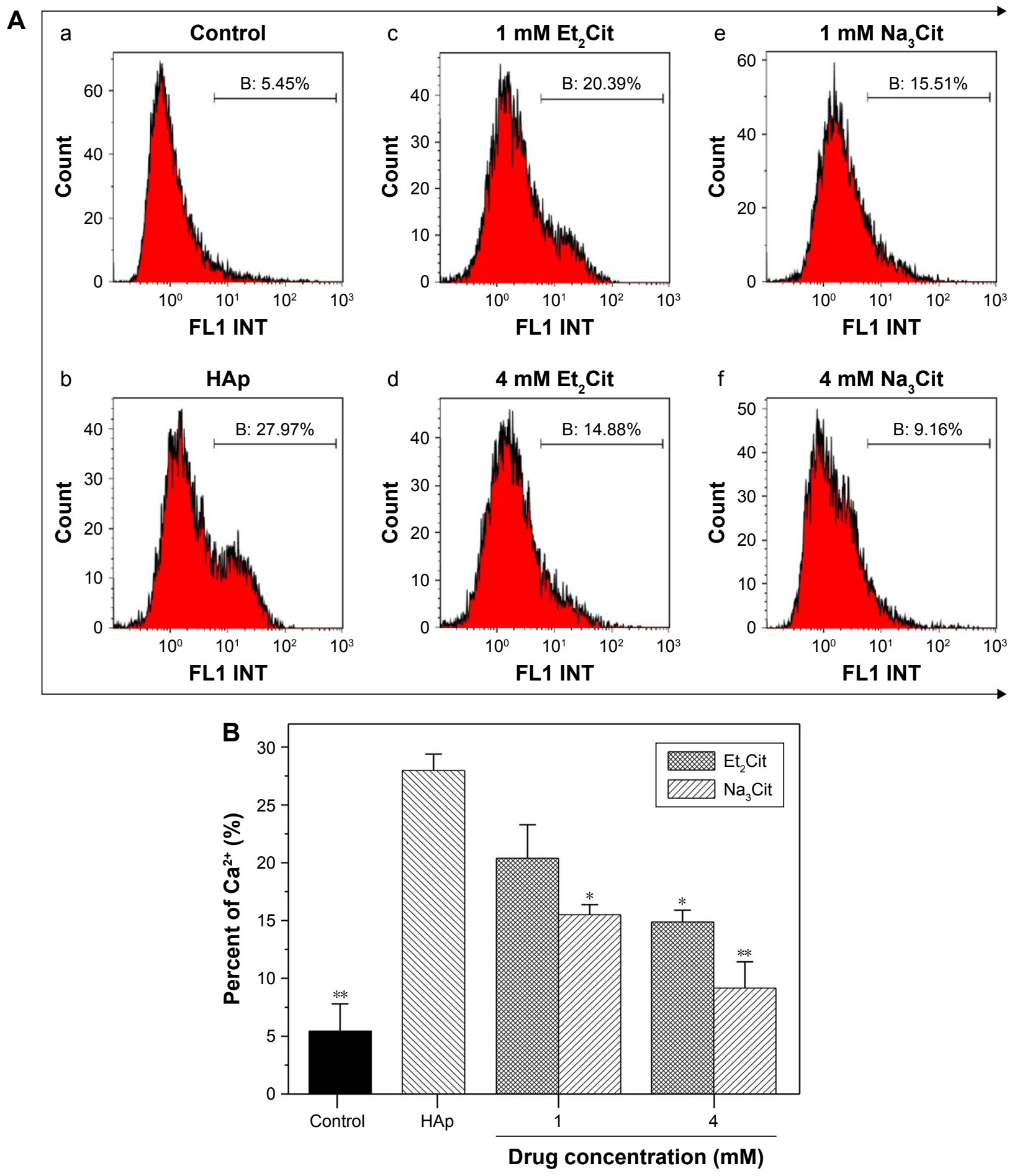

Figure 7 Effects of nano-HAp crystals on intracellular $\mathrm{Ca}^{2+}$ concentration in the presence of different concentrations of Et $\mathrm{Clt}_{2}$ and $\mathrm{Na}_{3} \mathrm{Cit}$ for $24 \mathrm{~h}$. (A) Dot plots of intracellular $\mathrm{Ca}^{2+}$ concentration. (B) Quantitative histogram of the percentage of cells stained by Fura-4/AM (*p<0.05, $* * p<0.01$ vs nano-HAp).

Abbreviations: $\mathrm{Et}_{2} \mathrm{Cit}$, diethyl citrate; $\mathrm{Na}_{3} \mathrm{Cit}$, sodium citrate; nano-HAp, nanosized hydroxyapatite.

a large amount of ROS and cell apoptosis. However, both $\mathrm{Na}_{3} \mathrm{Cit}$ and $\mathrm{Et}_{2}$ Cit can reduce HAp-induced cell apoptosis. The apoptotic bodies produced by apoptosis provide tuberculosis sites in the calcium phosphate deposition of VC. ${ }^{36}$ $\mathrm{Na}_{3} \mathrm{Cit}$ and $\mathrm{Et}_{2} \mathrm{Cit}$ can prevent HAp-induced apoptosis and retard the process of $\mathrm{VC} .{ }^{37}$
Nano-HAp induces necrosis of MOVASs and cytoprotective mechanism of $\mathrm{Et}_{2} \mathrm{Cit}$ and $\mathrm{Na}_{3} \mathrm{Cit}$

To investigate why nano-HAp induces cell necrosis of MOVASs (Figure 6), we tested whether $\mathrm{Na}_{3} \mathrm{Cit}$ and $\mathrm{Et}_{2} \mathrm{Cit}$ affect cellular $\mathrm{Ca}^{2+}$ and the damage of nano-HAp on lysosomes. 
A

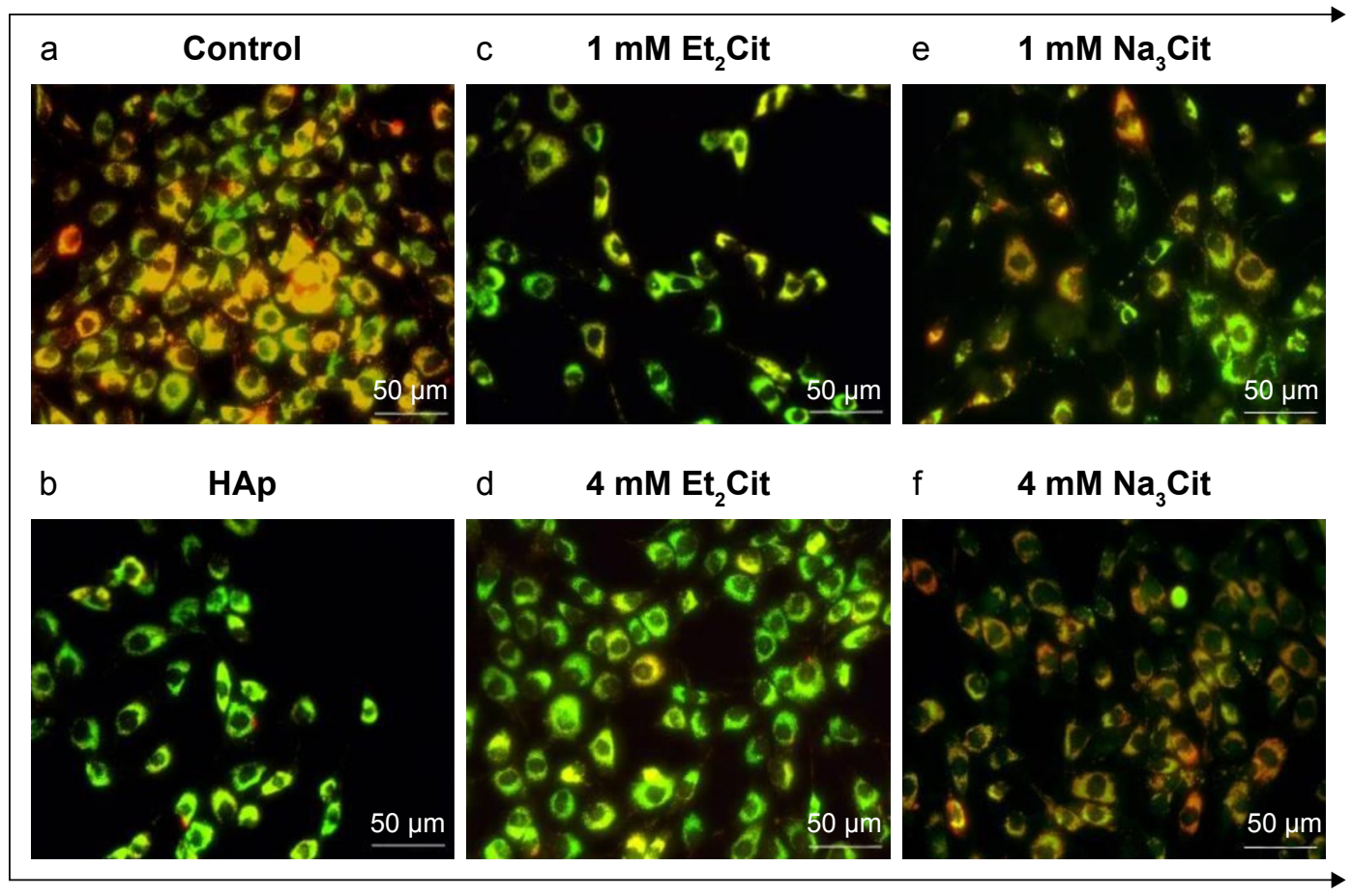

B

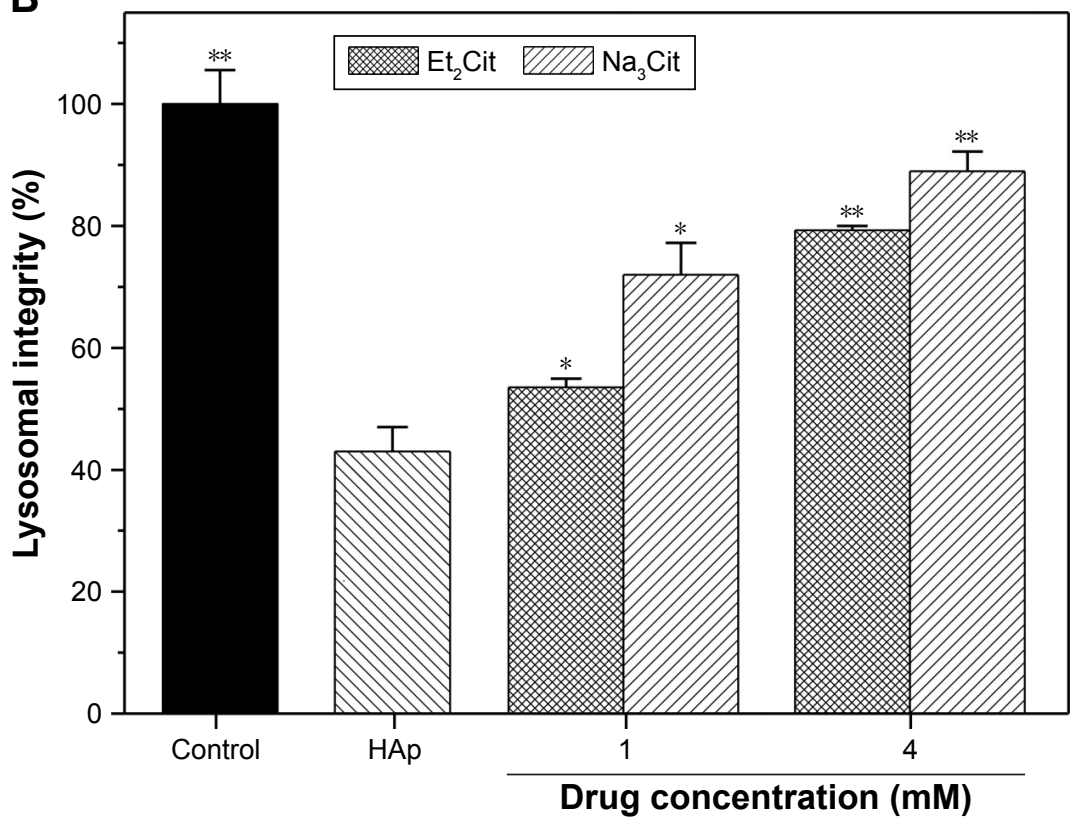

Figure 8 Lysosomal integrity of MOVASs after exposure to nano-HAp crystals in the presence of different concentrations of $\mathrm{Et}_{2} \mathrm{Cit}_{\mathrm{t}}$ and $\mathrm{Na}_{3} \mathrm{Cit}$ for $24 \mathrm{~h}$. (A) Fluorescence microscope observation. (B) Quantitative analysis of lysosomal integrity in MOVASs $(* p<0.05, * * p<0.01$ vs nano-HAp). Yellow-orange fluorescence represented complete lysosomes.

Abbreviations: $\mathrm{Et}_{2} \mathrm{Cit}$, diethyl citrate; MOVASs, mouse aortic smooth muscle cells; $\mathrm{Na}_{3} \mathrm{Cit}$, sodium citrate; nano-HAp, nanosized hydroxyapatite.

Cellular $\mathrm{Ca}^{2+}$ overload causes cytotoxicity and frequently results in necrotic, apoptotic, or autophagic cell death. ${ }^{38}$ Lysosomal rupture is an important feature of cell necrosis. . $^{39,40}$ Nano-HAp could induce an increase in the intracellular $\mathrm{Ca}^{2+}$ concentration (Figure 7) because nano-HAp that enters cells can be dissolved by lysosomes and lead to the release of a large amount of $\mathrm{Ca}^{2+}$. Meanwhile, nano-HAp could also damage the lysosome (Figure 8). This condition leads to an imbalance in cell self-repair and steady-state mechanism, thereby leading to cell necrosis. ${ }^{14,39}$ The addition of $\mathrm{Na}_{3} \mathrm{Cit}$ and $\mathrm{Et}_{2} \mathrm{Cit}$ could inhibit the increase in the intracellular $\mathrm{Ca}^{2+}$ concentration induced by nano-HAp and lysosomal damage.

Thus, nano-HAp induced an increase in the intracellular $\mathrm{Ca}^{2+}$ concentration, which led to lysosomal damage and cell 


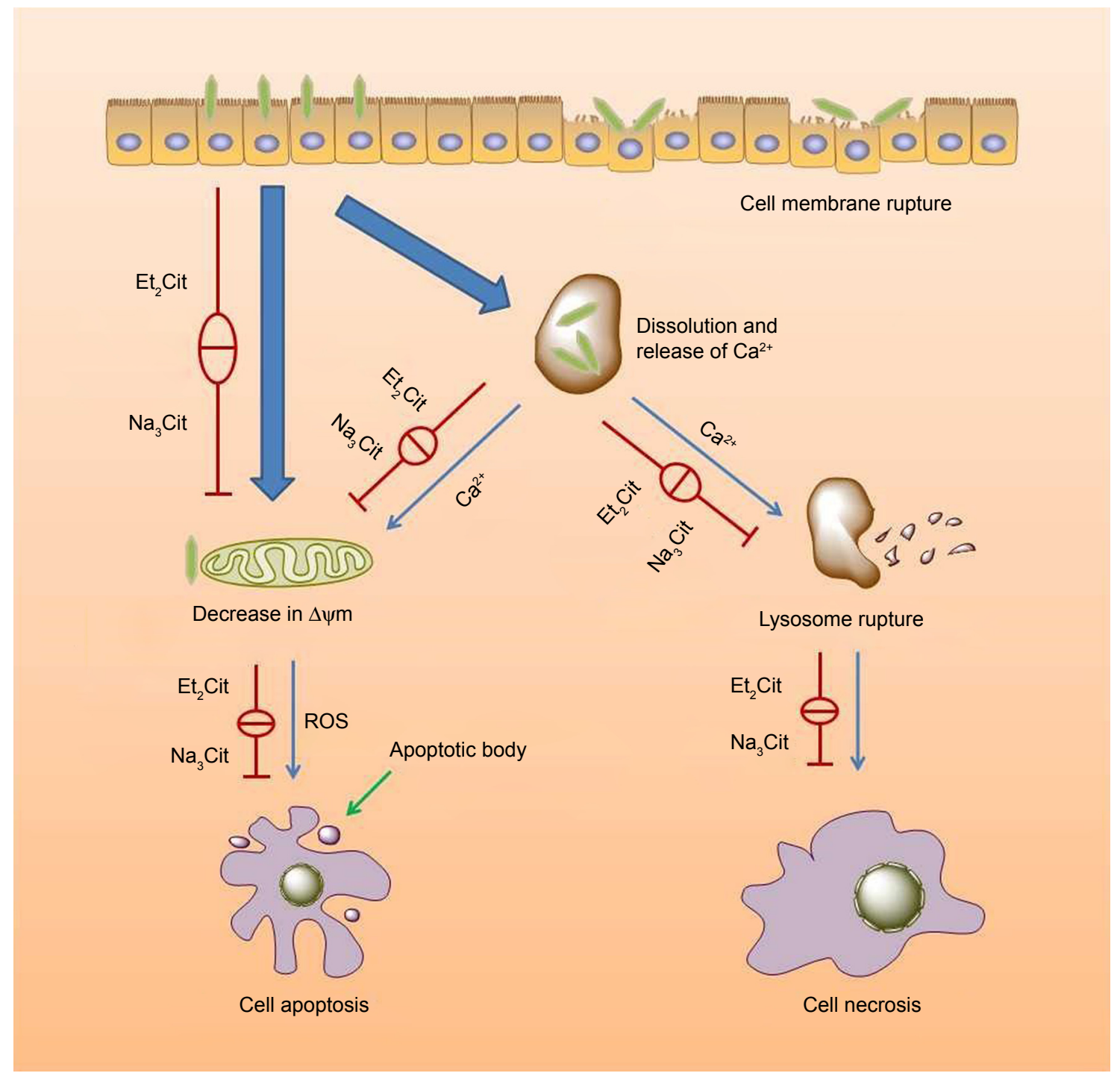

Figure $9 \mathrm{~A}$ proposed schematic illustration of cellular and molecular mechanism of $\mathrm{Et}_{2} \mathrm{Cit}$ and $\mathrm{Na}_{3} \mathrm{Cit}$ inhibiting injury of nano-HAp crystals on MOVASs.

Abbreviations: $\mathrm{Et}_{2} \mathrm{Cit}$, diethyl citrate; MOVASs, mouse aortic smooth muscle cells; $\mathrm{Na}_{3} \mathrm{Cit}$, sodium citrate; nano-HAp, nanosized hydroxyapatite; ROS, reactive oxygen species.

necrosis. This result was consistent with that obtained by Zhao et $\mathrm{al}^{41}$ and $\mathrm{Fu}$ et al. ${ }^{42}$

Given that lysosomal rupture is induced by the degradation of calcium phosphate, a dissolution inhibition might reduce lysosomal rupture.$^{39}$ Our previous study revealed that $\mathrm{Na}_{3} \mathrm{Cit}$ and $\mathrm{Et}_{2} \mathrm{Cit}$ can chelate with $\mathrm{Ca}^{2+}$ ions to form stable calcium citrate complexes. ${ }^{19}$ In addition, citrate can be adsorbed on the positively charged surface of calcium phosphate, thereby increasing the negative charges on the crystallite surface. ${ }^{43}$ The increase in negative charges of crystal may account for the delayed cellular uptake and the reduced plasma membrane damage of calcium phosphate particles. ${ }^{14}$ Therefore, $_{2}{ }_{2}$ Cit and $\mathrm{Na}_{3} \mathrm{Cit}$ might bind with high affinity to nano-HAp surface and alter the surface properties of calcium phosphate particles, thereby interfering with the exposure of calcium phosphate particles to the cell surface and inhibiting lysosomal dissolution of nano-HAp..$^{14,44}$ This occurrence slows the release of $\mathrm{Ca}^{2+}$ to the cytosol and reduces intracellular calcium increase, lysosomal damage, and necrosis of MOVASs. In addition, whether nano-HAp bound to $\mathrm{Et}_{2} \mathrm{Cit}$ and $\mathrm{Na}_{3} \mathrm{Cit}$ enters endosomes or lysosomes in MOVASs has yet to be determined.

\section{Differences in cytotoxicity-inhibiting effect of $\mathrm{Et}_{2} \mathrm{Cit}$ and $\mathrm{Na}_{3} \mathrm{Cit}$ on nano-HAp in MOVASs}

The stability constants of the complexes formed by $\mathrm{Na}_{3} \mathrm{Cit}$ and $\mathrm{Et}_{2} \mathrm{Cit}$ with $\mathrm{Ca}^{2+}$ at a ratio of 1:1 were 1988 and 231, respectively, at $\mathrm{pH} 7.4$ and $37^{\circ} \mathrm{C}^{20}{ }^{20} \mathrm{Tha}^{2+}$-chelating capacity of $\mathrm{Na}_{3} \mathrm{Cit}$ was greater than that of $\mathrm{Et}_{2} \mathrm{Cit}$. Therefore, the inhibitory effect of $\mathrm{Na}_{3} \mathrm{Cit}$ on increased $\mathrm{HAp}$-induced 
$\mathrm{Ca}^{2+}$ concentration was stronger than that of $\mathrm{Et}_{2} \mathrm{Cit}$ (Figure 7), and the ability of $\mathrm{Na}_{3} \mathrm{Cit}$ to inhibit lysosomal damage and cell necrosis was greater than that of $\mathrm{Et}_{2} \mathrm{Cit}$ (Figures 5 and 8).

$\mathrm{Na}_{3} \mathrm{Cit}$ and $\mathrm{Et}_{2} \mathrm{Cit}$ could effectively inhibit the cytotoxicity of nano-HAp on MOVASs, as well as the apoptosis and necrosis induced by nano-HAp, thereby weakening the process of VC. Therefore, $\mathrm{Et}_{2} \mathrm{Cit}$ and $\mathrm{Na}_{3} \mathrm{Cit}$ may play a role as anticoagulants in alleviating $\mathrm{VC}$ in patients with $\mathrm{CKD}$ in clinical applications. In addition, citrate is a treatment drug for calcium oxalate and HAp kidney stones. Citrate can bind intestinal and urine calcium and increase urine $\mathrm{pH}$, metabolize to bicarbonate, and decrease calcium excretion by reducing bone resorption and increasing renal calcium reabsorption. ${ }^{45,46}$ However, citrate binding to intestinal calcium may increase absorption and renal excretion of both phosphate and oxalate. ${ }^{45}$ Thus, the effect of oral citrate on urine calcium oxalate, calcium phosphate supersaturation, and VC is complex and difficult to predict. Moreover, calcification in vitro and in patients with CKD substantially varies. ${ }^{47}$ Further investigations are necessary to gain additional mechanistic insights into the mode of action of $\mathrm{Et}_{2} \mathrm{Cit}$ and $\mathrm{Na}_{3}$ Cit to prevent $\mathrm{VC}$.

\section{Conclusion}

Nano-HAp crystals decreased the viability and cell membrane damage of MOVASs and induced ROS production. Moreover, nano-HAp reduced $\Delta \psi \mathrm{m}$ and further increased intracellular ROS, which induced cell apoptosis. Nano-HAp also induced the increase in intracellular $\mathrm{Ca}^{2+}$ concentration and lysosomal damage, resulting in cell necrosis. Both $\mathrm{Et}_{2} \mathrm{Cit}$ and $\mathrm{Na}_{3} \mathrm{Cit}$ effectively reduced HAp-induced cell apoptosis or necrosis. At the same concentration, the inhibitory effect of $\mathrm{Na}_{3} \mathrm{Cit}$ was stronger than that of $\mathrm{Et}_{2} \mathrm{Cit}$ because of the stronger chelating function of $\mathrm{Na}_{3} \mathrm{Cit}$. This result could help elucidate the mechanism of HAp-induced VSMC damage and the possible protection mechanism of $\mathrm{Et}_{2} \mathrm{Cit}$ and $\mathrm{Na}_{3} \mathrm{Cit}$ on the vascular wall.

\section{Acknowledgment}

This work was supported by National Natural Science Foundation of China (No 81570673).

\section{Disclosure}

The authors report no conflicts of interest in this work.

\section{References}

1. Chen NX, Moe SM. Vascular calcification: pathophysiology and risk factors. Curr Hypertens Rep. 2012;14(3):228-237.
2. Kanbay M, Goldsmith D, Uyar ME, Covic A. Magnesium in chronic kidney disease: challenges and opportunities. Blood Purificat. 2010; 29(3):280-292.

3. Shroff R, Long DA, Shanahan C. Mechanistic insights into vascular calcification in CKD. J Am Soc Nephrol. 2013;24(2):179-189.

4. Louvet L, Büchel J, Steppan S, Passlick-Deetjen J, Massy ZA. Magnesium prevents phosphate-induced calcification in human aortic vascular smooth muscle cells. Nephrol Dial Transplant. 2013;28(4):869-878.

5. Demer LL, Tintut Y. Vascular calcification: pathobiology of a multifaceted disease. Circulation. 2008;117(22):2938-2948.

6. Lau WL, Festing M, Giachelli CM. Phosphate and vascular calcification: emerging role of the sodium-dependent phosphate co-transporter PiT-1. Thromb Haemost. 2010;104(3):464-470.

7. Liu Y, Zhang L, Ni Z, Qian JQ, Fang W. Calcium phosphate crystals from uremic serum promote osteogenic differentiation in human aortic smooth muscle cells. Calcified Tissue Int. 2016;99(5):543-555.

8. Sage AP, Lu J, Tintut Y. Hyperphosphatemia-induced nanocrystals upregulate the expression of bone morphogenetic protein-2 and osteopontin genes in mouse smooth muscle cells in vitro. Kidney Int. 2011; 2(4):414-422.

9. Hunter LW, Charlesworth JE, Yu S, Lieske JC, Miller VM. Calcifying nanoparticles promote mineralization in vascular smooth muscle cells: implications for atherosclerosis. Int J Nanomed. 2014;9(5): 2689-2698.

10. Kutikhin AG, Velikanova EA, Mukhamadiyarov RA, et al. Apoptosismediated endothelial toxicity but not direct calcification or functional changes in anti-calcification proteins defines pathogenic effects of calcium phosphate bions. Sci Rep. 2016;6(6):27255.

11. Smith ER, Hanssen E, McMahon LP, Holt SG. Fetuin-A-containing calciprotein particles reduce mineral stress in the macrophage. PLoS One. 2013;8(4):e60904.

12. Ewence AE, Bootman M, Roderick HL, et al. Calcium phosphate crystals induce cell death in human vascular smooth muscle cells. Circ Res. 2008;103(5):e28-e34.

13. Lei Y, Sinha A, Nosoudi N, Grover A, Vyavahare N. Hydroxyapatite and calcified elastin induce osteoblast-like differentiation in rat aortic smooth muscle cells. Exp Cell Res. 2014;323(1):198-208.

14. Dautova Y, Kozlova D, Skepper JN, Epple M, Bootman MD. Fetuin-A and albumin alter cytotoxic effects of calcium phosphate nanoparticles on human vascular smooth muscle cells. PLoS One. 2014; 9(5):e97565.

15. Chose N, Aytacoglu BN, Yilmaz N, et al. Citric acid as a decalcifying agent for the excised calcified human heart valves. Anadolu Kardiyol Derg. 2008;8(2):94-98.

16. Meng Y, Zhang H, Li Y, Li QN, Zuo L. Effects of unfractionated heparin on renal osteodystrophy and vascular calcification in chronic kidney disease rats. Bone. 2014;58(1):168-176.

17. Hu YY, Liu XP, Ma X, et al. Biomimetic self-assembling copolymer hydroxyapatite nanocomposites with the nanocrystal size controlled by citrate. Chem Mater. 2011;23(9):2481-2490.

18. Ou Y, Han J, Chen B, et al. Synthesis and characterization and anticoagulant properties of diethyl citrate. Asian J Chem. 2012;24(11): 4953-4960.

19. Han J, Xue JF, Xu M, Gui BS, Kuang L, Ouyang JM. Coordination dynamics and coordination mechanism of a new type of anticoagulant diethyl citrate with $\mathrm{Ca}^{2+}$ ions. Bioinorg Chem Appl. 2013; 2013(12):354736.

20. Ou Y, Chen B, Peng H, Gui BS, Yao XQ, Ouyang JM. Thermodynamic features of diethyl citrate calcium complexes and factors affecting the complex stability. Asian J Chem. 2012;24(10):4717-4722.

21. Chen Z, Chen B, Yao XQ, Gui BS, Ou Y, Ouyang JM. Anticoagulation of diethyl citrate and its comparison with sodium citrate in an animal model. Blood Purificat. 2012;33(1):30-36.

22. An L, Li W, Xu Y, Zeng DL, Cheng Y, Wang GH. Controlled additivefree hydrothermal synthesis and characterization of uniform hydroxyapatite nanobelts. Ceram Int. 2016;42(2):3104-3112. 
23. Mahmoodi S, Sorkhi L, Farrokhi-Rad M, Shahrabi T. Electrophoretic deposition of hydroxyapatite-chitosan nanocomposite coatings in different alcohols. Surf Coat Technol. 2013;216(2):106-114.

24. Khajuria DK, Razdan R, Mahapatra DR. Development, in vitro and in vivo characterization of zoledronic acid functionalized hydroxyapatite nanoparticle based formulation for treatment of osteoporosis in animal model. Eur J Pharm Sci. 2015;66(1):173-183.

25. Ma G, Yang W, Mariga AM, et al. Purification, characterization and antitumor activity of polysaccharides from Pleurotus eryngii residue. Carbohydr Polym. 2014;114:297-305.

26. Mittal M, Siddiqui MR, Tran K, Reddy SP, Malik AB. Reactive oxygen species in inflammation and tissue injury. Antioxid Redox Sign. 2014;20(7):1126-1167.

27. Aihara K, Byer KJ, Khan SR. Calcium phosphate-induced renal epithelial injury and stone formation: involvement of reactive oxygen species. Kidney Int. 2003;64(4):1283-1291.

28. Sanderson TH, Reynolds CA, Kumar R, Hüttemann M. Molecular mechanisms of ischemia-reperfusion injury in brain: pivotal role of the mitochondrial membrane potential in reactive oxygen species generation. Mol Neurobiol. 2013;47(1):9-23.

29. Xue Y, Zhang T, Zhang B, Fan G, Huang Y, Meng T. Cytotoxicity and apoptosis induced by silver nanoparticles in human liver HepG2 cells in different dispersion media. J Appl Toxicol. 2016;36(3):352-360.

30. Sun Y, Chen Y, Ma XY, et al. Mitochondria-targeted hydroxyapatite nanoparticles for selective growth inhibition of lung cancer in vitro and in vivo. ACS Appl Mater Interfaces. 2016;8(39):25680-25690.

31. Li N, Zhang Q, Gao S, et al. Three-dimensional graphene foam as a biocompatible and conductive scaffold for neural stem cells. Sci Rep. 2013;3(4):1604.

32. Sinha RA, Farah BL, Singh BK, et al. Caffeine stimulates hepatic lipid metabolism by the autophagy-lysosomal pathway in mice. Hepatology. 2014;59(4):1366-1380.

33. Draeger A, Monastyrskaya K, Babiychuk EB. Plasma membrane repair and cellular damage control: the annexin survival kit. Biochem Pharmacol. 2011;81(6):703-712.

34. Lobascio AM, De-Felici M, Anibaldi M, Greco P, Minasi MG, Greco E. Involvement of seminal leukocytes, reactive oxygen species, and sperm mitochondrial membrane potential in the DNA damage of the human spermatozoa. Andrology. 2015;3(2):265-270.

35. Jin Y, Liu XL, Liu HF, et al. Oxidative stress-induced apoptosis of osteoblastic MC3T3-E1 cells by hydroxyapatite nanoparticles through lysosomal and mitochondrial pathways. RSC Adv. 2017;7(21): 13010-13018.
36. Duan XH, Chang JR, Zhang J, et al. Activating transcription factor 4 is involved in endoplasmic reticulum stress mediated apoptosis contributing to vascular calcification. Apoptosis. 2013;18(9):1132-1144.

37. Ciceri P, Elli F, Braidotti P, et al. Iron citrate reduces high phosphateinduced vascular calcification by inhibiting apoptosis. Atherosclerosis. 2016;254(4):93-101.

38. Tay CY, Fang W, Setyawati MI, et al. Nano-hydroxyapatite and nanotitanium dioxide exhibit different subcellular distribution and apoptotic profile in human oral epithelium. ACS Appl Mater Interfaces. 2014; 6(9):6248-6256.

39. Liu Z, Xiao Y, Chen W, et al. Calcium phosphate nanoparticles primarily induce cell necrosis through lysosomal rupture: the origination of material cytotoxicity. J Mater Chem B. 2014;2(22):3480-3489.

40. Parkinsonlawrence EJ, Shandala T, Prodoehl M, Plew R, Borlace GN, Brooks DA. Lysosomal storage disease: revealing lysosomal function and physiology. Physiology. 2010;25(2):102-115.

41. Zhao X, Ng S, Heng BC, et al. Cytotoxicity of hydroxyapatite nanoparticles is shape and cell dependent. Arch Toxicol. 2013;87(6): 1037-1052.

42. Fu Q, Rahaman MN, Zhou N, Huang WH, Wang DP. In vitro study on different cell response to spherical hydroxyapatite nanoparticles. J Biomater Appl. 2008;23(1):37-50.

43. Duan CY, Xia ZY, Zhang GN, Xue JF, Ouyang JM. Changes in urinary nanocrystallites in calcium oxalate stone formers before and after potassium citrate intake. Int J Nanomed. 2013;8(3):909-918.

44. Smith ER, Cai MM, McMahon LP, et al. Serum fetuin-A concentration and fetuin-A-containing calciprotein particles in patients with chronic inflammatory disease and renal failure. Nephrology. 2013;18(3): 215-221.

45. Krieger NS, Asplin JR, Frick KK, et al. Effect of potassium citrate on calcium phosphate stones in a model of hypercalciuria. J Am Soc Nephrol. 2015;26(12):3001-3008.

46. Coe FL, Worcester EM, Evan AP. Idiopathic hypercalciuria and formation of calcium renal stones. Nat Rev Nephrol. 2016;12(9):519-533.

47. Hortells L, Sosa C, Millán Á, Sorribas V. Critical parameters of the in vitro method of vascular smooth muscle cell calcification. PLoS One. 2015;10(11):e0141751.
International Journal of Nanomedicine

\section{Publish your work in this journal}

The International Journal of Nanomedicine is an international, peerreviewed journal focusing on the application of nanotechnology in diagnostics, therapeutics, and drug delivery systems throughout the biomedical field. This journal is indexed on PubMed Central, MedLine, CAS, SciSearch $®$, Current Contents $\AA /$ Clinical Medicine,

\section{Dovepress}

Journal Citation Reports/Science Edition, EMBase, Scopus and the Elsevier Bibliographic databases. The manuscript management system is completely online and includes a very quick and fair peer-review system, which is all easy to use. Visit http://www.dovepress.com/ testimonials.php to read real quotes from published authors. 